\begin{tabular}{|l|l|l||}
\hline \multicolumn{2}{|c|}{ PublisherInfo } \\
\hline \hline PublisherName & $:$ & BioMed Central \\
\hline \hline PublisherLocation & $:$ & London \\
\hline \hline PublisherImprintName & $:$ & BioMed Central \\
\hline \hline
\end{tabular}

\title{
Pin-ning down breast cancer
}

\begin{tabular}{|l|l|l||}
\hline \multicolumn{2}{|c|}{ ArticleInfo } \\
\hline \hline ArticleID & $:$ & 4144 \\
\hline \hline ArticleDOI & $:$ & $10.1186 /$ gb-spotlight-20010711-01 \\
\hline \hline ArticleCitationID & $:$ & spotlight-20010711-01 \\
\hline \hline ArticleSequenceNumber & $:$ & 215 \\
\hline \hline ArticleCategory & $:$ & Research news \\
\hline ArticleFirstPage & $:$ & 1 \\
\hline \hline ArticleLastPage & $:$ & 2 \\
\hline \hline & $:$ & RegistrationDate : 2001-07-11 \\
ArticleHistory & $:$ & OnlineDate $: 2001-07-11$ \\
\hline \hline ArticleCopyright & $:$ & BioMed Central Ltd2001 \\
\hline \hline ArticleGrants & $:$ & \\
\hline \hline ArticleContext & $:$ & 130592211 \\
\hline \hline
\end{tabular}


Pin1, a member of a new family of phosphorylation-specific peptidyl-prolyl isomerases (PPIases), regulates mitosis and neuronal cell death in Alzheimer's disease. In the July 2 EMBO Journal, Wulf et al. propose a mechanism by which Pin 1 may contribute to cell proliferation in breast cancer cells (EMBO Journal 2001, 20:3459-3472). They found that Pin1 was overexpressed in breast cancer tissue and correlated with the tumour grade and with the level of cyclin D1 expression. Wulf et al.show that Pin1 activates the cyclin D1 promoter by binding to phosphorylated Ser63/73-Pro motifs in the c-Jun transcription factor and enhancing its transactivating function. In this way, Pin1 cooperates with oncogenic Ras to drive cyclin D1 expression and cell proliferation.

\section{References}

1. Sequence-specific and phosphorylation-dependent proline isomerization: a potential mitotic regulatory mechanism.

2. EMBO Journal, [http://intl.emboj.org]

This PDF file was created after publication. 